\title{
The First Report of Epidemic Pertussis by Bahaodowle Razi From the 15th Century Anno Domini
}

\author{
Hassan Yarmohammadi ${ }^{1,2}$; Mohamad H. Bahmani Kazeruni ${ }^{2}$; Amir Soofi ${ }^{1}$; Arman \\ Zargaran ${ }^{3, *}$ \\ ${ }^{1}$ Department of History of Medicine, Shiraz University of Medical Sciences, Shiraz, IR Iran \\ ${ }_{3}^{2}$ Research Office for the History of Persian Medicine, Shiraz University of Medical Sciences, Shiraz, IR Iran \\ ${ }^{3}$ Pharmaceutical Sciences Research Center, Department of Phytopharmaceuticals (Traditional Pharmacy), School of Pharmacy, Shiraz University of Medical Sciences, Shiraz, IR Iran \\ ${ }^{*}$ Corresponding Author: Arman Zargaran, Pharmaceutical Sciences Research Center, Department of Phytopharmaceuticals (Traditional Pharmacy), School of Pharmacy, Shiraz Uni- \\ versity of Medical Sciences, Shiraz, IR Iran. Tel: +98-7112304279, Fax:+98-7112304279, E-mail: zargarana@sums.ac.ir
}

Received: July 7, 2013; Revised: January 16, 2014; Accepted: November 27, 2014

\begin{abstract}
Background: Pertussis or "whooping cough" is an acute, communicable infection of the respiratory tract caused by the Gram-negative bacterium Bordetella pertussis. It has been recorded in history of medicine that the first pertussis epidemic was reported in 1578 by a French scientist, Guillaume de Baillou, in Paris. Furthermore, the causative agent was first isolated in 1906 by Jules Jean Baptiste Vincent Bordet and his brother-in-law Octave Gengou. However, it seems that earlier reports can be found in history of medicine.

Objectives: The aim of this study as to analyze the first Report of Epidemic Pertussis by Bahaodowle Razi From the 15th Century Anno Domini

Materials and Methods:We investigated a copy(Persian lithograph) of the book named "a summary of experiences in medicine", written by Bahaoddin-bin-Ghasem-Bahaoddin Razi (well known as Bahaodowle Razi) in 1502 to find the earliest existing report of epidemic pertussis in the history.

Results: Bahaodowle Razi, a Persian physician from the 15th century Anno Domini (AD), reported two epidemics in Harat and one in Rey (inold Persia) for the first time, one century before Baillou. He named it as Sorfe-ie-Am (meaning public cough).Those occurred during his lifetime. Explaining about his observations and experiences about this epidemic, Bahaodowle Razi elaborated on prognosis, symptoms, etiology and predisposing factors of pertussis.
\end{abstract}

Conclusions: This document shows that Bahaodowle Razi's report was the first report of epidemic pertussis in the medical history.

Keywords: History of Medicine; Whooping Cough; Persian Medicine

\section{Background}

Pertussis or "whooping cough" is an acute, communicable infection of the respiratory tract, caused by the Gram-negative bacterium Bordetella pertussis (1). This organism can make an epidemic disease in all races and in various climates $(2,3)$. Pertussis and its complications can sometimes lead to death, particularly in infants less than six months old (4). It is a fatal infection rooted in the history and its prevalence is about $20-40$ million and leads to 200,000 - 400,000 deaths annually worldwide in the current era (5).

\section{Objectives}

The aim of this study as to analyze the first report of epidemic Pertussis by Bahaodowle Razi from the 15th century Anno Domini.

\section{Materials and Methods}

It has been recorded in the history of medicine that the first pertussis epidemic was reported by a French scientist, Guillaume De Baillou, in Paris in 1578. He reported that pertussis occurred mostly in 4 - 10-month-old infants. However, Baillou did not explain the etiology, prognosis and management of this disease (6). The causative agent was first isolated by Jules Jean Baptiste Vincent Bordet and his brother-in-law Octave Gengou in 1906 (2).

\subsection{Bahaodowle Razi and his First Report of Pertus- sis Epidemic in the History}

Bahaoddin-bin-Ghasem-Bahaoddin Razi (well known as Bahaodowle Razi) has been considered as one of the most well-known Iranian physicians in the Islamic world since the 13th century (after Rhazes, Avicenna) $(7,8)$. He was born in Tarasht, Rey, in the late 15th century and passed away in 1509. The only book remained from Bahaodowle Razi is A summary of experiences in medicine, written in 1502 (9). This manuscript is compiled in 28 chapters (10). In the 13th

Copyright (C) 2015, Iranian Red Crescent Medical Journal. This is an open-access article distributed under the terms of the Creative Commons Attribution-NonCommercial 4.0 International License (http://creativecommons.org/licenses/by-nc/4.0/) which permits copy and redistribute the material just in noncommercial usages, provided the original work is properly cited. 
chapter of this book, Bahaodowle Razi has reported two epidemics in Harat and one in Rey (old Persia) for the first time (Figure 1). This occurred during his lifetime. Explain- ing about his observations and experiences about this epidemic, Bahaodowle Razi has elaborated on prognosis, symptoms, etiology and predisposing factors of pertussis.

Figure 1. The Page of the Book "A Summary of Experiences in Medicine"

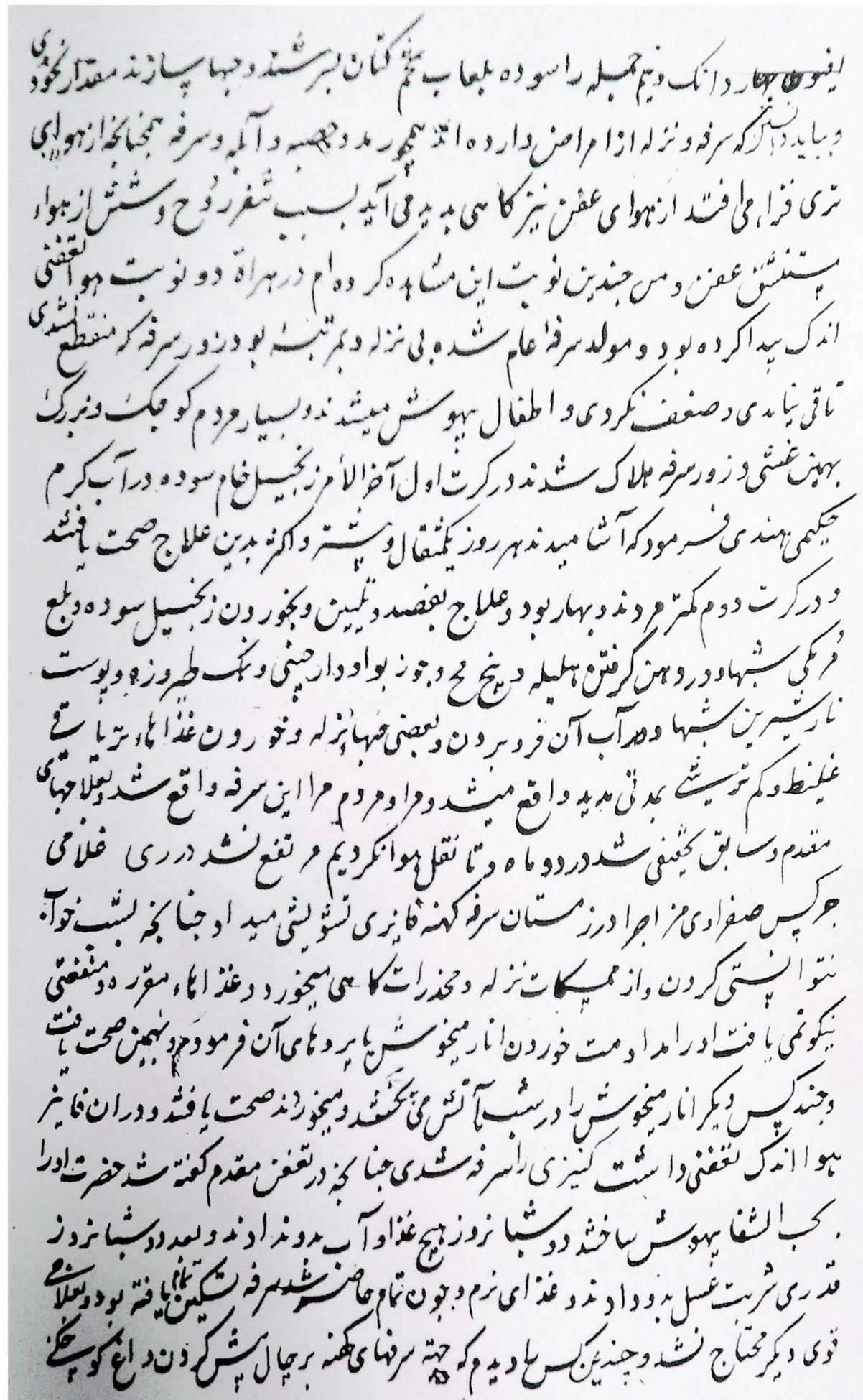

The photograph was provided by Dr. Zargaran. 


\section{Results}

In this part of his book, Bahaodowle Razi for the first time announced that an infective agent that enters the lungs via airborne pollution causes the disease. According to him, the moisture in the air is the precipitating factor for its transfer and the disease will not be controlled as long as the air is polluted. As its symptoms, he has mentioned that in this disease the patient is afflicted with dry cough without sputum; the coughs are consecutive and continual and sometimes are so severe that cause vomiting. These severe coughs usually lead to cyanosis. Moreover, the patient is wasted and listless, leading to anesthesia and death. He has also mentioned that children get involved by this illness more than adults. He called this epidemic disease Sorfe-ie-Am (meaning public cough) (11).

Bahaodowle Razi considered dissolved ginger (Zingiber officinale Roscoe) in water as an effective medication, clearly mentioning that by administration of this drug the mortality rate reduced, using the experience gained in the first epidemics (11). It is proven that ginger has antibacterial activity on Gram-negative bacteria (12). He explains that as long as the air is polluted, the epidemic is difficult to control, but the resultant mortality can be diminished (11).

\section{Discussion}

The review of the report in this book revealed that Bahaodowle Razi reported pertussis epidemic 100 years before the Baillou's report in Paris and indicated the role of airborne infective agent in transferring the disease. Therefore, he can be considered as the discoverer of pertussis throughout the history. It is based on current documents and can be valid until earlier document would be found.
After more than 500 years since the first pertussis epidemic report by Bahaodowle Razi, pertussis is still one of the childhood causes of death in Iran and its incidence is increasing in the community (13). This research was established in the national pertussis laboratory, Pasteur Institute of Iran, Tehran, in 2006 (5).

\section{Authors' Contributions}

Authors' contributions were equal.

\section{References}

1. Bjornstad ON, Harvill ET. Evolution and emergence of Bordetella in humans. Trends Microbiol. 2005;13(8):355-9.

2. Longo D, editor. Harrisons's principles of internal medicine. New York: McGraw Hill; 2011.

3. Cherry JD. Epidemic pertussis in 2012--the resurgence of a vaccine-preventable disease. N Engl J Med. 2012;367(9):785-7.

4. Kliegman RM, Stanton BMD, Geme JST, Schor N, Behrman RV, editor. Nelson textbook of pediatrics. United States: Elsevier Saunders; 2011.

5. Sedaghat M, Nakhost Lotfi M, Talebi M, Pourshafie MR. Status of Pertussis in Iran.JundishapurJ Microbiol. 2014;7(11):e12421.

6. Cone TJ. Whooping cough is first described as a disease sui generis by Baillou in 1640. Pediatrics. 1970;46(4):522.

7. Azizi MH. The otorhinolaryngologic concepts as viewed by Rhazes and Avicenna. Arch Iran Med. 2007;10(4):552-5.

8. Zarshenas MM, Mehdizadeh A, Zargaran A, Mohagheghzadeh A. Rhazes (865-925 AD). J Neurol. 2012;259(5):1001-2.

9. Tadjbakhsh $\mathrm{H}$. History of veterinary medicine and medicine of Iran. Tehran: Tehran Univ; 2006.

10. Velayati AA. Bahaodowle Razi. Quaternary J Islamic Iran Tradition Med. 2011;2(1):65-8.

11. Razi B. Kholasat al-Tajarob [A summary of experiences in medicine]. Tehran:Tehran Uni Med Sci; 2011.

12. Mascolo N, Jain R, Jain SC, Capasso F. Ethnopharmacologic investigation of ginger (Zingiber officinale). J Ethnopharmacol. 1989;27(1-2):129-40.

13. Shahcheraghi F, Nakhost Lotfi M, Nikbin VS, Shooraj F, Azizian R, Parzadeh M, et al. The First Macrolide-Resistant Bordetella pertussis Strains Isolated From Iranian Patients. JundishapurJ Microbiol. 2014;7(6):e10880. 